\title{
Research on the Challenges and Developmental Trend of Accounting Computerization in China under the Internet Background
}

\author{
Jingjing Cao \\ Hebei Polytechnic Institute, \\ Shijiazhuang,Hebei,050091 China
}

\author{
Dongliang Pan \\ Hebei Polytechnic Institute, \\ Shijiazhuang,Hebei,050091 China
}

\begin{abstract}
In this paper, we conduct research on the challenges and the developmental trend of the accounting computerization in China under the Internet background. With the development of China's network economy, Chinese enterprises will be more and more big, in order to meet the requirement of enterprise economic development, to expand its own field, so we should strengthen the enterprise management is to cultivate talents is very important, enterprise financial management is not only in terms of money should be enhanced, diversified development, in order to realize the network such as: capital investment, budget and the human resource management, internal audit, etc. With diversified development will inevitably produce security risks, so to strengthen the risk of computer is beneficial to the safety of the company. Our research starts form the analysis of the accounting computerization to propose the new paradigm for the corresponding development that is important.
\end{abstract}

Keywords- Challenges, Developmental Trend, Accounting Computerization, Internet.

\section{Introduction}

Information technology revolution and modern business globalization promoted the generation and development of knowledge economy, and will become the main power of economic growth within a certain scope. Informationization, globalization and innovation of economic priority are an important characteristic of knowledge economy. As is known to all, the influence of the economic environment of accounting system is enormous. Knowledge economy is based on the production, distribution and use of knowledge and information economy, the coming of the era of knowledge economy, inevitably lead to the impact of the modern accounting, and is likely to trigger a new accounting revolution. To determine the modern accounting from traditional financial accounting and management accounting to many new areas of the development. In a new era of the dramatic changes environment, knowledge economy strongly affects every aspect of modern accounting system. In this paper, combining with the characteristics of the change of era of knowledge economy accounting environment, accounting theory and practice of the new era of development trend makes the following discussion and analysis.

According to the literature survey, the characteristics of the accounting development could be list as the follows. (1) With the arrival of knowledge economy, the demand of information users, the great changes have taken place in the current measurement model for monetary unit of measurement, using the historical cost measurement attributes of defects are also increasingly prominent. (2) Accounting report system of the era of knowledge economy, no matter in the report of the content and scope, or on the report and the form of the transfer mode compared with the current report system will have greatly improved. (3) Type in the management accounting mode, the financial accounting and management accounting will be in harmony are an organic whole, accounting will be accounted into management accounting, in this type of management accounting mode, for 
users provide accounting information, accounting information should not only explain the absolute value, the relative value of the enterprise, as well as the relevant equity assets and the current or future performance of the debt paying ability, must also include ownership enterprise knowledge capital and knowledge innovation ability of basic information. (4) The future development of the economy, especially the various trading activities and trading means innovation, makes accrual basis and cash basis the trend of integration, this will be the future developing direction and orientation of the accounting theory [1-3].
Compared with the traditional way of the charge to an account, the accounting computerization has quick speed, high degree of automation, high precision, large storage capacity strong adaptability of the obvious advantages. But the security of the computerized accounting system also exist many of problems, seriously hindered the development of our country's accounting computerization deeper. The current development of the economy is becoming higher to the core requirement of the enterprise accounting information security to strengthen the security of computerized accounting as is necessary request to improve the management level of enterprise accounting.

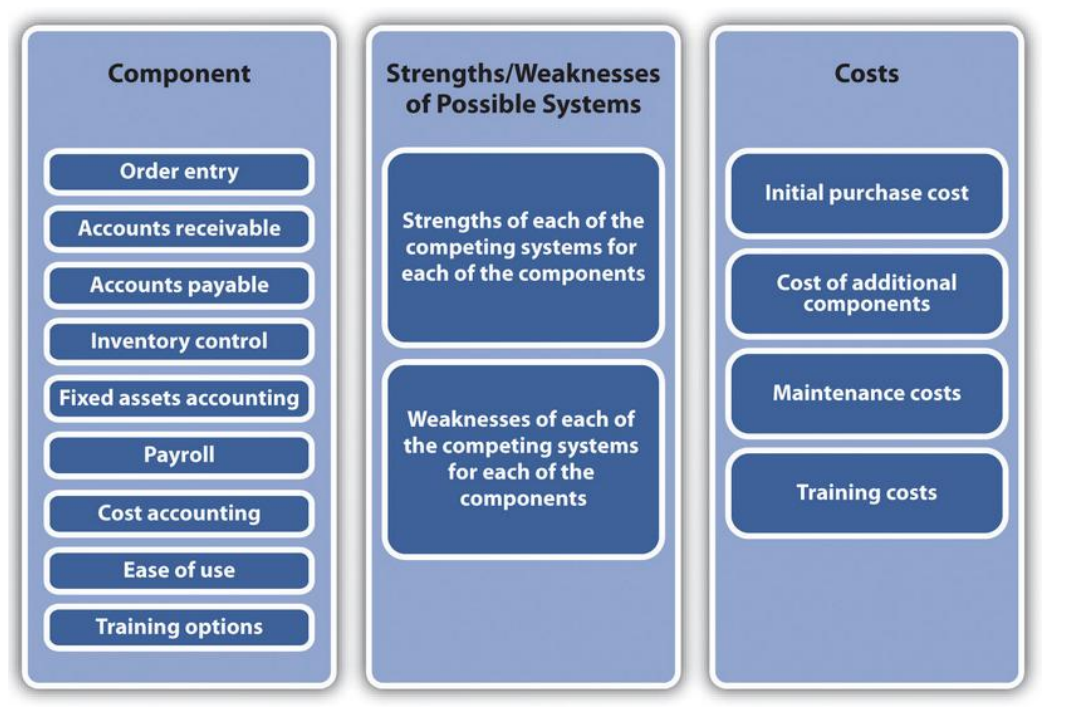

Figure 1. The Primary Concepts of the Accounting Computerization

In this paper, we conduct research on the challenges and developmental trend of the accounting computerization in China under Internet background. The development of enterprise, and enterprise internal financial sector has the close relation, the smooth running of the cashier as an important part of the financial sector, it is the same as accounting is conducted to the enterprise capital management and control of position, but difference is that the cashier functions primarily responsible for corporate and securities daily revenue and expenditures and keeping notes. Under the impetus of the science and technology, accounting computerization gradually spread to the work of financial department, then in such a situation, enterprises cashier more natural also gradually realize the working mode of counted, a qualified enterprise cashier personnel in addition to a variety of professional skills, to fully grasp the main technical points of the accounting computerization, such ability can keep pace with the times to improve work efficiency and quantity, and economic development play a positive role for enterprise. In the later sections, we will discuss these issues in detail. 


\section{The Proposed Methodology}

The Principles of the Accounting

Development. Accounting professional judgment is refers to the accounting personnel need to be in the face of uncertain accounting events, in accordance with the requirements of accounting standard for business enterprises and accounting regulations, according to characteristics of the economic environment of the business enterprise and management, to use their professional knowledge and professional experience, the accounting events processing and should adopt the principle, methods of preparation of financial reports, program, policy judgment and choice. Accounting personnel professional judgment ability is refers to the judgment in process of accounting professional judgment of accounting practitioners and the ability to choose [4-5].

Accounting internal control system is to show the enterprise internal in order to ensure the security of enterprise internal capital financial precision, information, accounting work efficiency, and a series of measures taken by the way, ultimate goal is to guarantee enterprise internal coordination accuracy of accounting information to maintain and promote the long-term development of the enterprise. It is important to note that the internal accounting control is a process of change, even the same enterprise in different periods, different stages of the development, the enterprise internal accounting control is different, so in economic development and enterprise management gradually scale under the premise of the need to establish a perfect internal control system to ensure the development of the enterprise.

Based on the literature survey, the features of the accounting can be listed as the follows. (1) There are specializing in, the core of the enterprise accounting management system is accounting system design. Due to the difference between different businesses, each enterprise has its own development characteristic, therefore in the process of design for the enterprise accounting system, the first thing to realize the characteristics of the enterprise development, then to make full use of the features of the enterprise itself to establish to tailor a set of accounting system suitable for their own development. (2) From the design of the accounting content and it contains the whole of the involved accounting management system, such as accounting, accounting procedure and accounting method, etc. From the point of accounting internal accounting system design basis, it should follow the reference, auditing, accounting or related and business management, organizational behavior theory and regulations. (3) Between the various elements in enterprise accounting system are closely linked together, interaction, mutually beneficial symbiosis, together to ensure that the enterprise stable operation and maintain the continuous development of the current enterprise [6].

Enterprise accounting internal control is the enterprise must have the less an important part of enterprise accounting internal control is able to affect the entire enterprise capital safety that can also affect the entire enterprise's future development planning. With the development of our country's economy, the increasingly accelerate the pace of reform and opening up, especially in the aspect of the economy construction, enterprise accounting internal control related work can improve the market competitiveness of enterprises, speed up the economic development of the health and safety.

The Accounting Computerization Concepts. "Accounting information" refers to the accounting information as management of information resources, comprehensive use of computer and network communication of information technology on acquisition, processing, transmission and application, such as processing, for enterprise operation and management, control, decision making and provide sufficient economic operation, the real-time and comprehensive information. Accounting information has the characteristics of 
universality, integration, dynamic and progressive, and the integration of the traditional accounting work that play a role in business accounting and financial processing, it also contains more content, such as the basic theory of the accounting information accounting information, informatization of education, management accounting information, etc.

Accounting computerization obtained widespread application in the field of accounting, now all of the almost all enterprises and institutions and all of the relevant departments to realize the accounting computerization, but how to under the environment of accounting computerization implementation of internal control, how to through effective measures to construct accounting computerization internal control system, thus more effectively to ensure that each unit of the property security and improve the efficiency of the computerization to provide information, it became an expert related research objects and important topic. The core aspects of enhancing accounting computerization are shown below.

- Theory is the precursor of action, the development of accounting computerization depends on the development of the theory of computerized accounting, computerized accounting theory research lag and would restrict the maturity and development of the computerized accounting software, therefore, computerized accounting theory is to guide and to promote the accounting computerization in the new practice guidelines for developing and perfecting [7].

- Strengthen the consciousness of the computerization and speed up the popularization of the computerized accounting. Group of managers in management activities to realize the use of efficient accounting information system to provide accurate information for decision making better service, but also to see the importance of financial business integration, build enterprise systems integration, promote the popularization of accounting computerization.

- Development of computer technology and information technology, such as the Internet, to the accounting computerization brought basic new shocks, e-commerce, network accounting and network finance has entered the field of accounting computerization. Enterprise to make the computerized accounting to adapt to the development of the times and it is necessary to use modern technology, using the new technology that development can meet the demand of the development of modern technology and a new type of accounting computerization.

The economic development of the demand for accounting computerization technology is more and more widely, electronic technology has a very important role on the processing of enterprise financial, enterprise managers should improve the importance of computerized accounting technology, improve staff awareness of the electronic technology, unceasingly renew the idea, such as the employees can be computerized accounting technology enterprise and the primary explain, for employees to have a comprehensive understanding of electronic technology, understand change way of computerization is not only a financial accounting and the data handling and storage form also have improved, so as to change the function of accounting work to improve work efficiency [8]. 


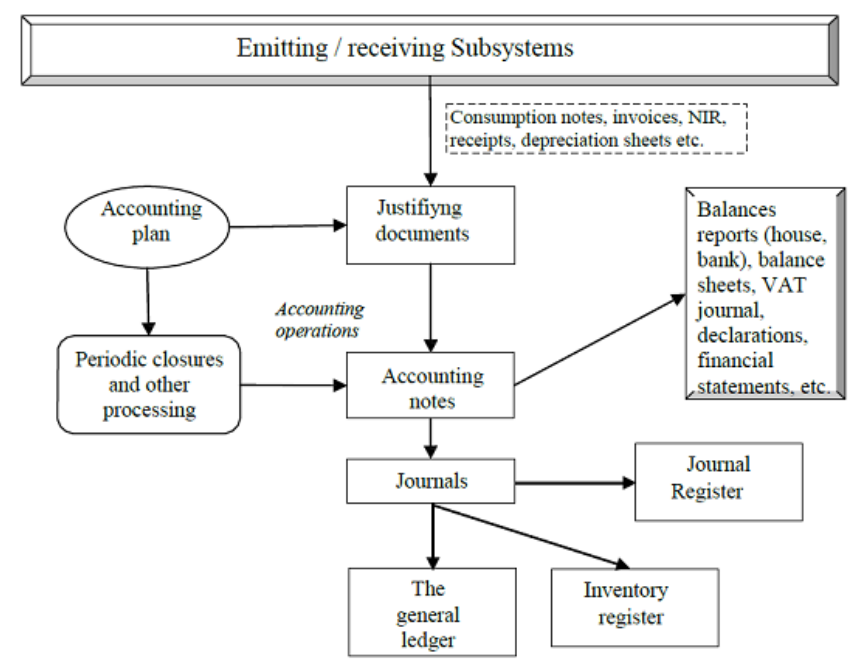

Figure 2. The Accounting Computerization Architecture

The Internet Accounting. Modern information technology, especially general the application and development of Internet technology in the field of the accounting is heralding the technology by the accounting computerization further to accounting information stage and network accounting has the following characteristics. (1) Breakthrough the limitation of the time and space, the network for the remote control of accounting can timely accurate, break through the geographical constraints, office, at any time can obtain desired information in a timely manner. (2) Accounting transaction processing, on the network accounting, a complex task can be distributed the multi-layer processing, finally get through computer summary report, in order to avoid data redundancy caused by human input. (3) Timely and comprehensive access to information, former basic finance department adopts manual bookkeeping, accounting work tedious lag, the waste of human resources, information is hard to find. (4) Enterprise's operation cost reduction, profit increase, the maximum to reduce costs, maximize profit and revenue for the company.

To strengthen the construction of accounting information under the internal control system. First of all, to ensure the reliability of the financial reporting information is one of the objectives of internal control system. Control performance of the control system in the process of information feedback, the feedback function is the important form of information connection and transfer. Through the control function of the feedback function, calibration information, improve the contact and transmission of information, and to realize the self-adjusting and perfecting of the system to reduce differences and the target. Out of the control system, information processing has lost its meaning. As the output of the accounting system, accounting information is the input of internal control system at the same time, in the process, through the role of the information feedback control system, perfected in the accounting information, and under the supervision of the control system and output information.

\section{Conclusion}

In this paper, we conduct research on the challenges and the developmental trend of the accounting computerization in China under the Internet background. In the Internet economy environment, the accounting system with computer and Internet technology, a new type of information processing tools to replace the traditional paper, pen and abacus and the displacement is not only a simple tool change is no longer a simple simulation of manual accounting, more important is that it brings to traditional accounting concept, theory and method of unprecedented, strong impact and reflection. If we are able to recognize this, and give full play to the potential of the modern information technology, we will be easier to face with the new opportunities and challenges brought by the knowledge economy era, to explore new mode of accounting development new period. In the later research, we will find out more integration of the Internet to enhance the accounting performance. 


\section{References}

[1] Lu, Kan, et al. "Problems and Solutions of Popularization of Accounting Computerization." Physics Procedia 33 (2012): 1155-1159.

[2] Chen, Ni. "The Problems of Accounting Computerization in SME and its Impact Research to Accounting Informationization." Electronic Test 12 (2013): 104.

[3] Wei, Peng. "On the Questions and Countermeasures of the Application of Accounting Computerization in the Geological Exploration Units." Science Mosaic 2 (2013): 050.

[4] Lei, K. A. N. G. "The problems and countermeasure to the internal control of computerized accounting system." Journal of Anhui Technical College of Water Resources and Hydroelectric Power 3 (2012): 037.

[5] Ismail, Noor Azizi, and Malcolm King. "Factors influencing the alignment of accounting information systems in small and medium sized Malaysian manufacturing firms." Journal of Information Systems and Small Business 1.1-2 (2014): 1-20.

[6] Kristal, Tali. "The capitalist machine: Computerization, workers' power, and the decline in labor's share within US industries." American Sociological Review 78.3 (2013): 361-389.

[7] Feng, Wang. "Research on Enterprise Operation with Finance and Accounting Cost Calculation Integration Framework System Based on IT Perspective." International Journal of Advancements in Computing Technology 4.19 (2012).

[8] Al-Hiyari, Ahmad, Mohammed Hamood Hamood AL-Mashre, and Nik Kamariah Nik Mat. "Factors that Affect Accounting Information System Implementation and Accounting Information Quality: A Survey in University Utara Malaysia." American Journal of Economics 3.1 (2013): 27-31. 